\title{
ANALISA PERBANDINGAN PENGGUNAAN BEGISTING SISTEM KUMKANG DENGAN BEGISTING SEMI KONVENSIONAL PADA GEDUNG BERTINGKAT
}

\author{
Moch. Khamim ${ }^{1}$, Sugeng Riyanto ${ }^{2}$, Mohamad Zenurianto ${ }^{3}$ \\ Jurusan Teknik Sipil Politeknik Negeri Malang \\ ${ }^{1}$ moch.chamim@gmail.com, ${ }^{2}$ Sugeng Riyanto@gmail.com, ${ }^{3}$ m.zenurianto@gmail.com \\ (Artikel diterima: Februari 2020, direvisi: April 2020, diterima untuk terbit: Juli 2020)
}

\begin{abstract}
Abstrak - Perencanaan acuan dan perancah pada proyek Apartemen Begawan Malang memiliki tiga pilihan alternatif antara lain metode konvesional, semi sistem dan sistem (KUMKANG). Skripsi ini bertujuan untuk membandingkan tiga alternatif pekerjaan acuan dan perancah dari sisi kekuatan material, waktu, dan biaya. Tahapan dalam melakukan penelitian yaitu : Pemilihan metode pelaksanaan balok, plat, dan kolom yang sesuai, perhitungan biaya, sehingga dapat dibandingkan dari segi biaya. Perhitungan durasi di dapat perbandingan durasi waktu pengerjaan. Dari segi biaya bekisting plat balok, Semi Konvensional lebih murah $25 \%$ dari Sistem Kumkang. Sedangkan dari segi waktu, Sistem Kumkang lebih cepat 80 hari dari Semi Konvensional. Sedangkan untuk bekisting kolom, dari segi biaya metode panel baja tiga kali lipat lebih murah dari metode semi sistem. Dari segi waktu, metode panel baja lebih cepat 90 hari dari metode semi sistem
\end{abstract}

Kata kunci: Acuan Perancah, Semi Konvensional \& Kumkang

\section{Pendahuluan}

Bangunan gedung bertingkat memiliki karakteristik yang spesifik khususnya dalam teknologi pelaksanaan seperti urutan pekerjaan, jenis pekerjaan, kegiatan pengangkutan vertikal, keselamatan kerja, keterbatasan lokasi dan air tanah. Metode pelaksanaan konstruksi yang terdiri dari pekerjaan persiapan, dewatering, struktur bawah, struktur atas dan finishing perlu direncanakan sebelum pelaksanaan pekerjaan. Pelaksanaan struktur atas beton pada dasarnya dapat dilaksanakan dengan berbagai metode : Cast inplace/cast insitu, komponen struktur dicor ditempatnya. Termasuk metode konvensional ; Campuran precast dan Cast inplace, digunakan dengan berbagai macam kombinasi antara balok, plat dan kolom ; Precast, komponen struktur dicor dipabrik

Formwork atau cetakan beton sering juga disebut bekisting merupakan suatu sarana pembantu untuk mencetak beton dengan ukuran, bentuk rupa ataupun posisi serta aligment yang dikehendaki. Bekisting terdiri dari beberapa bagian yang dirangkai menjadi suatu kesatuan konstruksi tertentu dengan system yang praktis. Artinya sesuai dengan sifatnya hanya merupakan struktur sementara yang mendudukung beratnya sendiri dan berat beton basah, konstruksi bekisting harus mudah dikerjakan dan mudah pula untuk dibongkar serta tidak mudah rusak sehingga dapat dipakai berulang kali. Hal yang perlu diperhitungkan adalah bekisting harus mampu menahan beban-beban yang ada.

Bekisting semi sistem adalah bekisting yang bahan dasarnya disesuaikan dengan konstruksi beton, sehingga pengulangannya dapat dilakukan lebih banyak apabila konstruksi beton itu sendiri tidak terjadi perubahan bentuk maupun ukuran.

Adapun bekisting sistem adalah bekisting yang mengalami perkembangan lebih lanjut kesebuah bekisting universal yang dengan segala kemungkinannya dapat digunakan pada berbagai macam bangunan, penggunaan bekisting sistem bertujuan untuk penggunaan ulang pakai.

\section{Tinjauan Pustaka}

\section{A. Definisi Acuan dan Perancah}

Yang dimaksud dengan acuan dan perancah adalah konstruksi sementara yang berfungsi sebagai cetakan atau mal untuk beton cair hingga mengeras menjadi struktur bangunan, sesuai dengan bentuk dan ukuran yang telah direcanakan. Kemudian acuan dan perancah ini akan dibongkar setelah beton mencapai cukup umur.

Kualitas bekisting ikut menetukan bentuk dan rupa konstruksi, sehingga harus dibuat dari bahan yang bermutu dan perlu direncanakan sedemikian rupa supaya konstruksi tidak mengalami kerusakan akibat lendutan yang timbul ketika beton di tuang. Bekisting dan perancah adalah suatu konstruksi yang berfungsi untuk memberikan bentuk pada sisi samping dan bawah dari konstrukso yang diinginkan, diaman sambungan-sambungan antara papan bekisting tidak boleh bocor, supaya campuran air semen yang akan melicinkan permukaan beton tidak keluar. Oleh karena itu, supaya tercapai bentuk yang direncanakan, acuan harus kaku (perubahan-perubahan bentuk sedikit sekali), dan juga harus stabil supaya tidak terjadi kecelakaan selama pengecoran beton.

F. Wigbout (1992 : 106) mengatakan bahwa dalam perencanaan beban suatu bekisting diperhatikan beberapa faktor, antara lain beban yang ditopang, penggunaan bekisting yang berulang kali, faktor cuaca, keausan perancah akibat hentakan, getaran dan pembebanan yang tidak merata. Ada dua jenis beban yang terjadi pada bekisting, yaitu beban vertikal dan horizontal. Beban vetikal merupakan beban bekisting yang ditahan oleh konstruksi penopang, sedang beban horizontal merupalam beban yang terjadi akibat beban angin dan pelaksanaan yang tidak sesuai rencana.

Menurut Wigbout (1987:233) pada umumnya bekisting secara garis besar dibagi menjadi 3 tipe, yaitu :

a. Bekisting tradisional 
Yang dimaksud dengan bekisting tradisional adalah bekisting yang setiap kali setelah dilepas dan dibongkar menjadi bagian-bagian dasar, dapat disusun kembali menjadai sebuah bentuk lain. Pada umumnya bekisting kontak terdiri dari kayu papan atau material plat, sedangkan konstruksi penopang disusun dari kayu balok dan (pada lantai) dari stempelstempel baja. Bekisting tradisional ini memungkinkan pemberian setiap bentuk yang diinginkan pada kerja beton.

\section{b. Bekisting setengah sistem}

Yang dimaksud bekisting setengah sistem adalah satuansatuan bekisting yang lebih besar, yang direncanakan untuk sebuah obyek tertentu. Untuk ini mereka pada prinsipnya digunakan untuk berulang-ulang kali dalam bentuk tidak diubah. Pada umumnya bekisting kontak terdiri dari material plat. Konstruksi penopang disusun dari komponen-komponen baja yang dibuat di pabrik atau gelagar-gelagar kayu yang tersusun. Setelah usai, komponen-komponen ini dapat disusun kembali menjadi sebuah bekisting setengah sistem untuk sebuah obyek yang lain. Contoh : Elemen-elemen panel dinding

\section{c. Bekisting sistem}

Yang dimaksud dengan bekisting sistem adalah elemenelemen bekisting yang dibuat di pabrik, sebagian besar komponen-komponen yang terbuat dari baja. Bekisting sistem dimaksudkan untuk penggunaan berulang kali. Ini berarti bahwa tipe beksiting ini dapat digunakan untuk sejumlah pekerjaan. Bekisting sistem dapat pula disewa dari penyalur alat-alat beksiting. Contoh : Bekisting panel untuk terowongan, bekisting untuk beton pre-cast.

\section{Pembiayaan Acuan dan Perancah}

Edward G Nawy (1997 : 1) biaya bekisting biasanya berkisar antara $35 \%$ sampai $60 \%$ atau lebih dari pada keseluruhan biaya konstruksi struktur beton. Menyadari pengaruh harga pekerjaan bekisting terhadap biaya keseluruhan, adalah kritis bagi engineer struktur untuk memfasilitasi ekonomi bagi bekisting, tidak hanya ekonomis bagi material beton. Ada beberapa pertimbangan yang dijadikan acuan dalam penetuan konstruksi bekisting yang ekonomis :

1. Biaya dan kemungkinan terhadap penyesuaian material yang telah ada dibanndingkan dengan membeli atau menyewa material baru.

2. Biaya dari tingkat kualitas material yang lebih tinggi dibandingkan dengan tingkat yang rendah plus keahlian pekerja yang lebih baik dalam peningkatan kualitas dan kegunaan.

3. Pemilihan terhadap material yang lebih mahal sehingga dapat menghasilkan daya tahan dan kapasitas penggunaan dibandingkan dengan material yang lebih murah dengan tingkat pengguanaan yang lebih pendek.

4. Penyeltelan di lokasi dibandingkan dengan penyetelan di took atau pabrik. Hal ini tergantung dari kondisi serta lahan yang tersedia, ukuran besar kecilnya proyek, jarak tempat penyetelan, dan lain sebagainya.
James M Antil, Paul W.S Ryan (1982 : 213) penggunaan yang berulang dari bekisting ditujukan untuk mencapai nilai ekonomis maksimum dari material. Panel-panel bekisting sebaiknya dirancang agar mudah dipasang, dibongkar dan diperkuat sehingga keuntungan maksimum dapat diperoleh tanpa mengeluarkan banyak biaya perbaikan.

Pekerjaan yang paling sulit sehubungan dengan bekisting adalah mengestimasi biaya bekisting tersebut. Para estimarit harus memperhatikan faktor-faktor yang mempengaruhi dan berkaitan dalam menghitung pembiayaan pekerjaan dan mencapai suatu efisiensi. Faktor-faktor tersebut yaitu :

1. Jenis metode yang dipakai, hal ini berhubungan dengan pemilihan jenis material, alat bantu dan penyangga perkuatan yang dipakai serta jenis pengadaannya (beli atau sewa).

2. Pemilihan tenaga kerja, ketrampilan dan harga upah menjadi pertimbangan.

3. Metode fabrikasi, pemasangan, perkuatan, pembongkaran, dan pemindahan.

Edwar G Nawy (1997 : 3) estimasi biaya konstruksi dari pekerjaan bekisting dapat diperoleh dengan menjumlahkan kuantitas material kayu yang diperlukan untuk menghasilkan $1 \mathrm{~m}^{2}$ area kontak, disamping memperhitungkan pula sisa potongan material, kemudian dikalikan dengan harga satuan kayu tersebut.

Estimasi dalam perlaksanaan konstruksi bekisting harus diperhitungkan pula waktu kerja untuk mendirikan dan membongkar bekisting tiap siklus. Dalam perhitungan waktu tersbut, kontraktor harus memperthitungkan pula tundaan akibat cuaca, permasalahan alat disamping proses pemberishan bekisting dan pekerjaan lainnya.

\section{TAHAP DAN PROSEDUR PENELITIAN}

Tahapan dalam analisis data merupakan urutan langkah yang dilaksanakan secara sistematis dan logis sesuai dasar teori permasalahan sehingga didapat analisis yang akurat untuk mencapai tujuan penulisan. Adapun tahap dan prosedur penelitian yang akan dilakukan adalah sebagai berikut :

\section{Tahap I (Tahap persiapan)}

Langkah yang dilakukan yaitu merumuskan masalah penelitian, tujuan penelitian, menentukan metode yang digunakan dan menggali kepustakaan. Melakukan studi pustaka yaitu dengan membaca meteri kuliah, buku-buku referensi, buku-buku, dan jurnal yang berhubungan dengan pembuatan laporan penelitian.

2. Tahap II (Tahap penentuan obyek penelitian), langkah yang dilakukan adalah :

a. Mengidentifikasi proyek yang akan diteliti.

b. Melakukan proses perijinan kepada pelaksana atau pemilik proyek.

c. Menetukan obyek pengamatan.

3. Tahap III (Tahap pengumpulan data) 
Langkah-langkah yang dilakukan dalam tahap ini sebagai berikut :

Mengumpulkan data proyek yang dijadikan obyek penelitian, berupa data sekunder dari kontraktor pelaksana dan pengawas yang bertanggung jawab atas pelaksanaan proyek. Dari observasi diperoleh data sebagai berikut :

- Gambar struktur proyek

- Menggunakan daftar harga satuan pekerjaan konstruksi (HSPK) wilayah Kota Malang dari Cipta Karya.

4. Tahap IV (Tahap analisis data)

Adapun langkah yang dilakukan adalah :

a. Menentukan metode pelaksanaan setiap alternatif.

b. Menghitung biaya dan rencana anggaran biaya (RAB) dari 2 alternatif tersebut.

c. Melakukan penjadwalan pekerjaan bekisting.

5. Tahap V (Tahap pembahasan)

Langkah yang dilakukan adalah membahas penelitian perbandingan bekisting dari 3 alternatif metode bekisting plat, balok, dan kolom.

\section{A. Metode Pemasangan Perancah}

Proses pembongkaran bekisting bergantung pada kecepatan mengerasnya beton, dan baru dibongkar setelah ditanyakan aman. Pembuatan dan pemasangan bekisting tergantung dari banyak faktor yang mempengaruhi yaitu bahan yang tersedia atau yang diperlukan, cara dan pengadaan tenaga kerja, tuntutan akan hasil pengerjaan yang dibutuhkan terutama terutama dalam hal akurasi dan kerapian serta biaya alat-alat yang digunakan.

Pengangkatan beton pada bekisting dapat dihindari dengan melumasi penampang bekisting yang bersentuhan itu dengan minyak bekisting. Namum pemakaian minyak bekisting tidak boleh terlalu banyak karena dapat merubah warna permukaan beton. Apabila papan bekisting dikerjakan dengan sederhana, maka papan bekisting dapat dipakai sekitar 3 sampai 5 kali. Sedangkan untuk balok persegi dan bulat dapat dipakai sekitar 7 sampai 10 kali. Bekisting hendaknya disusun rapih sehingga dpat dipergunakan kembali. (Widhyawati, Yana, et.al 2010)

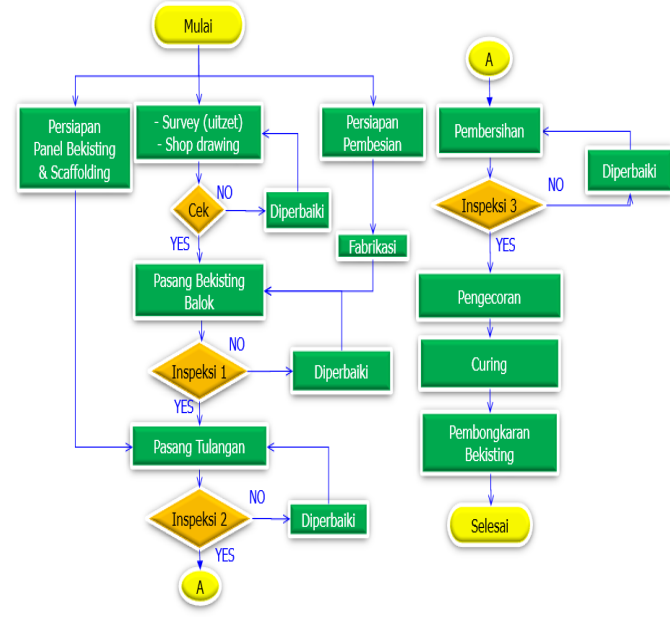

B. Diagram Alir

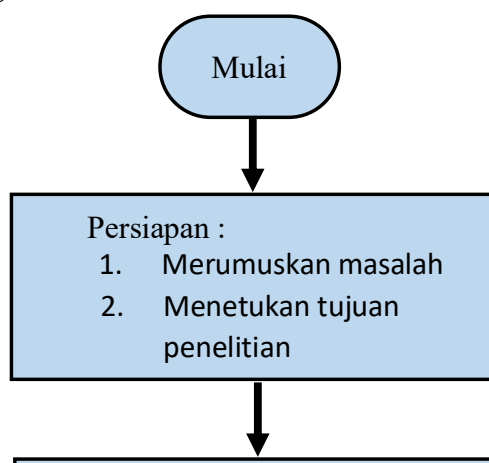

Survey Pustaka :

1. Menentukan obyek penelitian

2. Studi literatur

Teknik Pengumpulan Data :

Mengumpulkan data primer yang dijadikan obyek penelitian dari kontraktor pelaksana dan pengawas yang bertanggung jawab atas pelaksanaan proyek pembangunan gedung tersebut.

Alternatif dan metode pelaksanaan

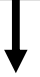

Analisis Biaya dan waktu Bekisting

1. Biaya pembuatan pelat, balok, dan kolom

2. Penjadwalan pekerjaan bekisting

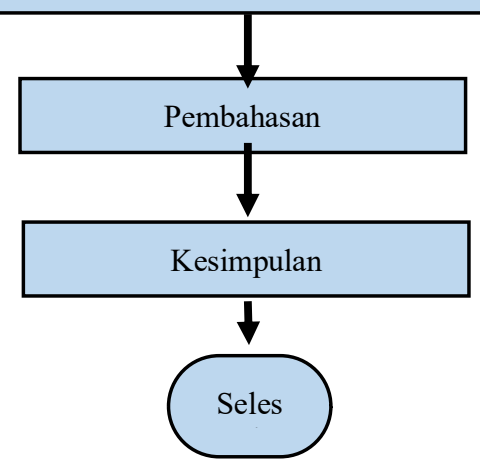

Menurut (SNI 03-2847-2002), pelaksanaan pekerjaan harus memenuhi persyaratan yang diberlakukan. Dalam hal ini perencanaan bekisting, pembongkaran bekisting dan penopang, serta penopang kembali 
Jurnal Teknik: Ilmu dan Aplikasi Vol. 09 No. 2, Juli 2020

Tabel Strategi Pelaksanaan Bekisting Balok Plat Semi Konvensional.

\begin{tabular}{|c|c|c|c|}
\hline Pekerjaan & $\begin{array}{c}\text { Detail } \\
\text { Pekerjaan }\end{array}$ & Material \& Alat & $\begin{array}{c}\text { Tenaga } \\
\text { Kerja }\end{array}$ \\
\hline 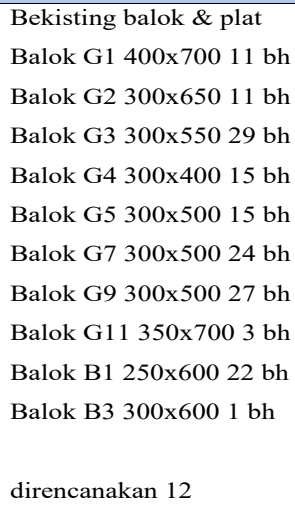 & $\begin{array}{l}\text { Pasang } \\
\text { Bekisting balok } \\
\text { dan plat }=12 \\
\text { hari }\end{array}$ & $\begin{array}{l}\text { Material : } \\
\text { Plywood } 12 \mathrm{~mm}, \\
\text { jack base \& } U \\
\text { head, scaffolding } \\
\text { ringlock, besi } \\
\text { hollow 4x6, besi } \\
\text { double canal, } \\
\text { tierod, paku. } \\
\text { Alat : } \\
\text { Palu, gergaji, } \\
\text { meteran, } \\
\text { waterpass. }\end{array}$ & $\begin{array}{l}\text { Md } 1 \text { org } \\
\text { Tk } 4 \text { org } \\
\text { Pk } 8 \text { org }\end{array}$ \\
\hline hari/lantai & $\begin{array}{l}\text { Pembongkaran } \\
\text { bekisting } \\
\text { setelah beton } \\
\text { umur } 28 \text { hari = } \\
2 \text { hari }\end{array}$ & $\begin{array}{l}\text { Alat: } \\
\text { Linggis, palu }\end{array}$ & $\begin{array}{l}\text { Md } 1 \text { org } \\
\text { Tk } 4 \text { org } \\
\text { Pk } 8 \text { org }\end{array}$ \\
\hline
\end{tabular}

\begin{tabular}{|c|c|c|c|}
\hline Pekerjaan & $\begin{array}{c}\text { Detail } \\
\text { Pekerjaan }\end{array}$ & Material \& Alat & $\begin{array}{c}\text { Tenaga } \\
\text { Kerja }\end{array}$ \\
\hline 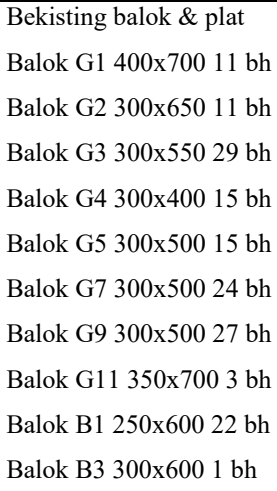 & $\begin{array}{l}\text { Pasang } \\
\text { Bekisting balok } \\
\text { dan plat = } 12 \\
\text { hari }\end{array}$ & $\begin{array}{l}\text { Material : } \\
\text { Plat besi } 6 \mathrm{~mm}, \\
\text { jack base \& } U \\
\text { head, pipa steger, } \\
\text { balok peri, balok } \\
\text { suri-suri, tierod, } \\
\text { paku. } \\
\text { Alat: } \\
\text { Palu, meteran, } \\
\text { waterpass. }\end{array}$ & $\begin{array}{l}\text { Md } 1 \text { org } \\
\text { Tk } 2 \text { org } \\
\text { Pk } 4 \text { org }\end{array}$ \\
\hline $\begin{array}{l}\text { direncanakan } 9 \\
\text { hari/lantai }\end{array}$ & $\begin{array}{l}\text { Pembongkaran } \\
\text { bekisting } \\
\text { setelah beton } \\
\text { umur } 28 \text { hari = } \\
2 \text { hari }\end{array}$ & $\begin{array}{l}\text { Alat: } \\
\text { Linggis, palu, } \\
\text { kunci inggris. }\end{array}$ & $\begin{array}{l}\text { Md } 1 \text { org } \\
\text { Tk } 2 \text { org } \\
\text { Pk } 4 \text { org }\end{array}$ \\
\hline
\end{tabular}

Tabel Strategi Pekerjaan Bekisting Kolom Semi Konvensional

\begin{tabular}{|c|c|c|c|}
\hline Pekerjaan & $\begin{array}{c}\text { Detail } \\
\text { Pekerjaan }\end{array}$ & $\begin{array}{c}\text { Material \& } \\
\text { Alat }\end{array}$ & $\begin{array}{c}\text { Tenaga } \\
\text { Kerja }\end{array}$ \\
\hline $\begin{array}{l}\text { Bekisting balok \& plat } \\
\text { Kolom NC1 }(500 \times 1250) 17 \text { bh } \\
\text { Kolom NC2 }(500 \times 1250) 5 \text { bh } \\
\text { Kolom NC3 }(500 \times 1250) 5 \text { bh } \\
\text { Kolom EC1 }(500 \times 800) 11 \text { bh } \\
\text { Kolom EC2 }(500 \times 800) 5 \text { bh } \\
\text { Kolom EC3 }(500 \times 800) 3 \mathrm{bh} \\
\text { Kolom EC5 (500x800) } 1 \text { bh } \\
\text { direncanakan } 1 \text { hari/lantai }\end{array}$ & $\begin{array}{l}\text { Pasang } \\
\text { Bekisting } \\
\text { kolom = } 1 \\
\text { hari untuk } \\
\text { semua } \\
\text { kolom pada } \\
\text { zona } 1 \\
\text { sampai zona } \\
3 .\end{array}$ & $\begin{array}{l}\text { Material : } \\
\text { Plywood, besi } \\
\text { hollow } 4 / 6, \\
\text { paku, tie rod. } \\
\text { Alat : } \\
\text { Palu, meteran, } \\
\text { gergaji, } \\
\text { waterpass, } \\
\text { unting-unting. }\end{array}$ & $\begin{array}{l}\text { Md } 1 \text { org } \\
\text { Tk } 4 \text { org } \\
\text { Pk } 8 \text { org }\end{array}$ \\
\hline & $\begin{array}{l}\text { Pembongkar } \\
\text { an bekisting } \\
\text { setelah } \\
\text { beton umur } \\
12 \text { jam = } 1 \\
\text { hari }\end{array}$ & $\begin{array}{l}\text { Alat: } \\
\text { Linggis, palu. }\end{array}$ & $\begin{array}{l}\text { Md } 1 \text { org } \\
\text { Tk } 4 \text { org } \\
\text { Pk } 8 \text { org }\end{array}$ \\
\hline
\end{tabular}

Strategi Pekerjaan Bekisting Kolom Sistem Kumkang

\begin{tabular}{|c|c|c|c|}
\hline Pekerjaan & $\begin{array}{c}\text { Detail } \\
\text { Pekerjaan }\end{array}$ & $\begin{array}{c}\text { Material \& } \\
\text { Alat }\end{array}$ & $\begin{array}{c}\text { Tenaga } \\
\text { Kerja }\end{array}$ \\
\hline $\begin{array}{l}\text { Bekisting balok \& plat } \\
\text { Kolom NC1 }(500 \times 1250) 17 \text { bh } \\
\text { Kolom NC2 }(500 \times 1250) 5 \text { bh } \\
\text { Kolom NC3 }(500 \times 1250) 5 \text { bh } \\
\text { Kolom EC1 }(500 \times 800) 11 \text { bh } \\
\text { Kolom EC2 }(500 \times 800) 5 \text { bh } \\
\text { Kolom EC3 }(500 \times 800) 3 \text { bh } \\
\text { Kolom EC5 (500x800) } 1 \text { bh } \\
\text { direncanakan } 1 \text { hari/lantai }\end{array}$ & $\begin{array}{l}\text { Pasang } \\
\text { Bekisting } \\
\text { kolom }=1 \\
\text { hari untuk } \\
\text { semua } \\
\text { kolom pada } \\
\text { zona } 1 \\
\text { sampai zona } \\
3 .\end{array}$ & $\begin{array}{l}\text { Material: } \\
\text { Bekisting panel } \\
\text { baja, tie rod. } \\
\text { Alat: } \\
\text { Palu, meteran, } \\
\text { waterpass, } \\
\text { unting-unting. }\end{array}$ & $\begin{array}{l}\text { Md } 1 \text { org } \\
\text { Tk } 2 \text { org } \\
\text { Pk } 4 \text { org }\end{array}$ \\
\hline
\end{tabular}

Tabel Strategi Pelaksanaan Bekisting Balok Plat Sistem Kumkang

Tabel Biaya pembuatan $1 \mathrm{~m}^{2}$ bekisting plat lantai 


\begin{tabular}{|c|c|c|c|c|}
\hline \multirow[b]{2}{*}{ Uraian Pekerjaan } & \multicolumn{2}{|c|}{ Volume $\mathrm{m}^{2}$} & \multirow{2}{*}{$\begin{array}{c}\text { Harga / } \mathbf{m}^{2} \\
\text { (Rp) }\end{array}$} & \multirow{2}{*}{$\begin{array}{l}\text { Total } \\
\text { (Rp) }\end{array}$} \\
\hline & $\begin{array}{c}\text { Balok } \\
\text { Plat }\end{array}$ & Kolom & & \\
\hline Semi Konvensional & \multirow{6}{*}{4011,4} & \multirow{6}{*}{657,22} & & \\
\hline Bekisting balok dan plat & & & $1.100 .000,00$ & $4.412 .540 .000,00$ \\
\hline Bekisting kolom & & & $950.000,00$ & $624.359 .000,00$ \\
\hline Sistem Kumkang & & & & \\
\hline Bekisting balok dan plat & & & $1.725 .000,00$ & 6.919.665.000,00 \\
\hline Bekisting kolom & & & $1.010 .000,00$ & $663.792 .200,00$ \\
\hline
\end{tabular}

Perbandingan total biaya dan waktu.

\begin{tabular}{|l|c|c|c}
\hline \multicolumn{1}{|c|}{ Pekerjaan } & $\begin{array}{c}\text { Durasi } \\
\text { (hari) }\end{array}$ & Biaya (Rp) & $\begin{array}{c}\text { Kemudahan } \\
\text { Pembongkaran }\end{array}$ \\
\hline Bekisting Balok Plat & & & Mudah dibongkar \\
\hline Semi Sistem & 430 & $12.942 .165 .645,12$ & Mudah dibongkar \\
\hline Sistem Kumkang & 350 & $19.904 .543 .047,83$ & \\
\hline Bekisting Kolom & & & Mudah dibongkar \\
\hline Semi Sistem & 150 & $2.818 .969 .639,22$ & Sangat mudah dibongkar \\
\hline Sistem Kumkang & 60 & $687.188 .721,62$ & \\
\hline
\end{tabular}

\section{KeSIMPULAN}

Berdasarkan dari tabel di atas, semua alternatif masingmasing mempunyai keunggulan dan kelemahan. Dari segi biaya bekisting plat balok, Semi Sistem lebih murah $25 \%$ dari Sistem Kumkang . Sedangkan dari segi waktu, Sistem Kumkang lebih cepat 80 hari dari Semi Konvensional. Sedangkan untuk bekisting kolom, dari segi biaya metode panel baja tiga kali lipat lebih murah dari metode semi sistem. Dari segi waktu, metode panel baja lebih cepat 90 hari dari metode semi sistem

\section{Daftar Pustaka}

[1] Wigbout, F, Ing. 1992. Pedoman Tentang Bekisting (Kotak Cetak). Elangga: Jakarta

[2] Wijayanto, Budi, M. Yudi Purnawan, Sukamta dan Arif Hidayat. 2014. Metode Pelaksanaan Dan Analisa Biaya Bekisting Pada Pekerjaan Struktur (Studi Kasus : Pembangunan Gedung Astra Honda Motor Semarang). Semarang: Universitas Diponegoro.

[3] Edwar G Nawy. 2013. Aplikasi Pengendalian Waktu Pelaksanaan Pekerjaan Proyek. Menado: Universitas Sam Ratulangi 